\title{
Migration studies: an imposition
}

Willem Schinkel(iD

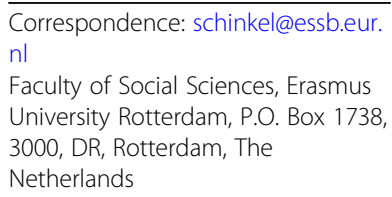

\begin{abstract}
This is a rejoinder to the responses made to my paper "Against "immigrant integration": For an end to neocolonial knowledge production', which was based on my book Imagined Societies. A Critique of Immigrant Integration in Western Europe (Cambridge University Press, 2017). Here, I aim to push the boundaries of our discussion a bit further by arguing that the point is not to come up with better concepts of 'immigrant integration'. Rather, it is to recognize that any such concern with, and for, 'integration' is already an imposition, and that, perhaps, the thing conventionally called 'migration studies' should be seen as, itself, an imposition.
\end{abstract}

Keywords: Migration studies, Immigrant integration, Social science, Neocolonialism, Europe

\section{An indefensible position}

There is nothing defensible in the concept of immigrant integration, and neither in anything that purports to be an 'alternative' for it, since any such alternative is destined to remain bound up with the very position from which social scientists once decreed their findings concerning 'integration'. 'Integration' itself is but one outgrowth of a more general fetish with a position called 'modernity', an imagined project of 'us', the civilized, secular, liberal, liberated who have the courtesy to take up the burden of bringing 'them' up to speed, of including 'them' in what is inevitable anyway. That position is indefensible. It is a twisted position, one that claims to be an epistemic position but that is really only possible through the perpetuation of domination, of academic but convertible forms of privilege, and of the active suppression of the imagination of other modalities of living together. To problematize the ways we speak about immigrant integration' can never be a way to better calibrate the concept, to shore it up, or to come up with alternatives. It must be a problematization of the very claim to the position from which one might deploy such a concept or anything that could pass as an 'alternative' to it. Whether that position announces itself by way of reference to a certain 'society', or to 'Europe', to 'the West', or to 'modernity' (and it tends to be all of these in mixed constitutions), the position is indefensible. It is indefensible because it has always only been possible on the basis of the very work that 'integration' now does: to identify the other, to manage her/him, in order to secure the order of 'society', of 'Europe', which has been possible only through histories of capitalist expansion and colonial plunder. Any claim to a purely epistemic position is undercut by the sheer fact that the reference categories we are invested in ('society', 'Europe,' 'universal humanity') are historical categories, and we are enlisted in the state work that seeks to reaffirm

(c) The Author(s). 2019 Open Access This article is distributed under the terms of the Creative Commons Attribution 4.0 International License (http://creativecommons.org/licenses/by/4.0/), which permits unrestricted use, distribution, and reproduction in any medium, provided you give appropriate credit to the original author(s) and the source, provide a link to the Creative Commons license, and indicate if changes were made. 
them, to reproduce their plausibility, their ahistoricity, their legitimacy. If we can learn anything from this exchange, it might be that we are all, each of us and in different ways, invested in a position that is, ultimately, indefensible and not in our or in anyone's interest. And if we want to learn more, the only way is to listen to voices of those who, by fate or fortune, have had to liberate themselves from that position. These voices undercut our entire discussion, revealing the clumsiness of our disagreements, our amateurism in grappling with vocabularies - race, whiteness, coloniality - and our just-on-the-sceneness when it comes to reconceiving the very conceptions of human sociality and of the world that we are always already invested in, always already working within and outward from. At least, when I speak for myself, I am a novice. Long before I was born Aimé Césaire had said it all: "Europe is indefensible" (Césaire, 2000, p. 32). It took me 15 years in academia to get to it (and I blame both myself and the structure of 'academia' for this), and to even start to grapple with this predicament of that which enables everything in the production of which I have participated. Fanon said it too: "Europe is literally the creation of the Third World" (Fanon, 2002, p. 99). How apt a description of the productivity of so much of what we have nobly termed 'migration studies'! Or, in yet another way, I am struck by a structural similarity when Sylvia Wynter writes about the postcolonial condition:

"the West is now going to reincorporate us neocolonially, and thereby mimetically, by telling us that the problem with us wasn't that we'd been imperially subordinated, wasn't that we'd been both socioculturally dominated and economically exploited, but that we were underdeveloped" (Wynter, 2015, p. 20).

I can imagine the migration scholar think 'but that's got nothing to do with our efforts to chart immigrant integration or diversity!' But has it really? Don't these very concepts only make sense by always already accepting what are ultimately political concepts, political conceptions of this 'society', of this 'Europe', as if these are givens. My entry point into discussions about what is gathered under the broad rubric of 'migration' has always been that it is impossible to treat conceptions of collectivity as givens, and to then chart what goes on 'in', across, or between such collectivities under the name of 'migration'. The point is that we don't have a conception of 'society' without it being an effect of a whole host of problematizations that go by the name of 'migration' and that are enacted by state apparatuses, some of which are academic. And with those problematizations come a host of other conceptions, of subjectivity and even of humanity, that social scientists tend not to question with the result that they end up reifying historically particular, Western-centric notions as if these were universals. Taking the 'science' part in 'social science' seriously means precisely to question the most taken-for-granted conceptions, and to come up with alienating vocabularies and sometimes bewildering findings, in order to escape the constant threat of what Bourdieu (2012) called 'state thought'.

\section{"No conflicts of interest were reported by the author"...}

So between me and at least some of my interlocutors, discussion really already dries up if it should be about what happens when people 'settle in a society' or when 'migration' is considered not as an effect of an elaborate state work of 
visualization (Dijstelbloem, van Reekum, \& Schinkel, 2017; van Reekum \& Schinkel, 2017) but as 'people moving from one country to another'. And discussion dries up when it should be about defending existing notions of integration or diversity or about coming up with alternatives that, under conditions of acceptance of state conceptions of collectivity and of migration ('people moving'), inevitably end up operating in functionally equivalent ways. So there is really no way to respond to proposals for 'relational integration' without rehearsing the fact that such notions reproduce all the problems inherent in the very idea of an 'integration' analytically separable from what would be a 'society' (what else would that yield than a re(in)statement of 'modernization theory'?), as is the case in Lea Maria Klarenbeek's (2019) response. The same goes for Rinus Penninx's (2019) effort to save immigrant integration research. In his response, he appears to presume that 'whiteness' is a concept that refers to skin color. And it is precisely such a resistance to learning from others (he might start with an interview one of the editors of this journal conducted with bell hooks: Grünell \& Saharso, 1999) that is so problematic also when people coin concepts like 'super-diversity'.

Fran Meissner's (2019) eloquent and measured critique of my intervention rightly points out that I don't discuss the strongest possible version of 'super-diversity', and that there are many. That is true. In a recent metastudy, Steven Vertovec, who coined the concept, groups the following seven ways in which it is used: "a contemporary synonym of diversity, a backdrop for a study, a call for methodological reassessment, a way of simply talking about more ethnicity, a multidimensional reconfiguration of social forms, a call to move beyond ethnicity, and a device for drawing attention to new social complexities" (Vertovec, 2019, p. 125). Quite apart from the fact that the 'discovery' of the other is the discovery of 'complexity' (there's super-diversity now, but things were so much simpler when whiteness was so ubiquitous that it didn't even show up), I would say the concept is 'used' in yet another way: as a way of not seriously speaking about race and power. Why, in the face of so much work by critical race scholars and postcolonial scholars, would 'super-diversity' be the new rallying concept if not for the many disavowals and political neutralizations it affords while at the same time providing continuity - even 'progress', 'increasing insight' or whatever - in the careers of migration scholars? The disavowal of history is one issue here, for the idea that now there's 'super-diversity' exists only as ex post facto affirmation and reification of everything it claims to now complexify, and under conditions of the ahistoricity of its conceptual elements. The disavowal and displacement of race is perhaps the most obvious and pertinent. And, as Ahmed (2012) has illustrated, is that not exactly the way 'diversity' operates in the university, in the very (infra)structures that organize the production of knowledge about 'super-diversity'?

Even if, as Vertovec says, 'super-diversity' was coined to call attention to "new hierarchical social positions, statuses or stratifications" (Vertovec, 2019, p. 126), it was utterly redundant given the wealth of concepts and insights coming from disciplines such as critical race studies, Black Studies and postcolonial studies. Its success, even in its most reflexive versions, I would venture, has to do with the apolitical and hence policy-friendly blandness the word 'super-diversity' evokes and with the concomitant disavowals that the concept 'super-diversity' enacts. So perhaps one could say that all seven ways of using 'super-diversity' share a common interest, meaning that there is something unintentionally disingenuous to the disclosure statement following Vertovec's paper (and so many others): "No potential conflict of interest was reported by the author" (Vertovec, 2019, p. 136). 
In that respect, the position taken by Leila Hadj Abdou (2019) is very sympathetic: 'immigrant integration' and, I would add, 'super-diversity', says more about those interested in it than about those whose condition or status it purports to describe. It is, she contends, a form of 'governance of ethno-cultural differences'. I can concur, although I would prefer a concept over governmentality over against the neo-liberal jargon of 'governance', even though I see that it is precisely under conditions of neo-liberalism that a particular modality of governing prevails, as Hadj Abdou (2019) illustrates with respect to urban government. The point of my intervention was precisely to recognize the ongoing academic complicity, even across what the field considers to be progress by way of different integration concepts or by replacing such concepts by concepts of (super-)diversity. And my aim was to not merely note that complicity but to specify it as a neo-colonial modality of government and to denounce it. I believe Adrian Favell's (2019) 12 theses are very much in line with this, and, by way of placing bordering processes front and center, they point to a possible way forward. So does Meissner's (2019) call to be attentive to the various ways in which methods enact realities, which has been central to my own work in recent years.

At the same time, there is a more fundamental unease here. In a way, any attempt to academically accept the state-mediated 'object' of 'migration' and to start to meddle with those whom it is thought to concern, as if poking an alien life form to see if it is in fact alive, is an imposition in, and on, the social world, an imposition that is the product of an active choice not to recognize the entanglement that allows one to do this and to reify the separation that state-thought imposes but that is always illusory. There is a certain violence already in the purely intra-academic, routinized yet arbitrary normalcy with which one decides 'I'm going to study this' and starts to produce 'knowledge' about those people that state-thought construes as the subjects (and hence objects) of 'migration'. In order to be attuned to this violence, many of us must learn to learn, by bringing in voices that tend to be little heard in 'migration studies'. Apart from those already mentioned here, I believe that, in Europe at least, one voice that deserves our undivided attention is Houria Bouteldja's.

\section{Dismantling integrationism: Houria Bouteldja's Whites, Jews and Us}

In Whites, Jews and Us: Toward a Politics of Revolutionary Love (2017), Houria Bouteldja undercuts anything European academics might conduct by way of discussion about the 'problem' of 'migration' and 'migrant settlement' in Europe - and I'm deliberately phrasing this in the broadest sense possible. Bouteldja, one of the founders of Indigènes de la République, occupies a position outside of the terrain of positionality of 'debates about immigration' in Europe, and for this reason, her book is an act of generosity and a pedagogy. Whites, Jews, and Us is written against the European 'Left'. But when she speaks of a political-ideological apparatus she calls the 'white immune system', it is clear that the notion of the 'Left' is restrictive and that 'migration studies' can be readily perceived to be part of this immune system - even without giving credence to right-wing accusations of 'left-wing academia', because even a generously expansive conception of 'the Left' as including social-democratic positions does not capture all that exists under the umbrella of migration studies. What does this 'white immune system' consist of? It is, first and foremost, characterized by innocence. Obviously, everything that now goes by the name of 'integration' or 'diversity' has its historical antecedents in colonial history, and what are now 
called 'immigrants' in Europe are in so many ways part of the delayed, or ongoing, responses to the initial plunder conducted in the name of Europe - "they were born wretched of the earth, and they ended up immigrants" (Bouteldja, 2017, p. 104). Yet the language of otherness unleashed on 'immigrants' is riddled with best intentions. Best intentions aimed at 'improving' the 'situation of immigrants', at furthering their 'integration', their 'inclusion' or their 'mobility', and best intentions aiming at 'policy-relevance,' are the jargon of whiteness that communicates 'innocence'. Recalibrating what Baldwin (1998, p. 604) called Europe's 'racial innocence', this innocence, for Bouteldja as for Wekker (2016), is a 'white innocence'. As Bouteldja says: 'Paradoxically, you 'discover' that you are white - especially the French - when we call you 'white'. In reality, you discover nothing. You simply recoil at being named, situated, your guilt thereby uncovered and your immunity rendered vulnerable" (Bouteldja, 2017, p. 42). And so we might get away too easily as academics when we generously 'turn the tables' and critically consider those who have an interest in 'integration' and 'super-diversity' unless we do so in a language that recognizes the workings of whiteness as a mode of domination. If we don't, we end up congratulating ourselves with our reflexivity and sophistication, a chauvinism of guilt that ends up reinforcing what Bouteldja describes as the 'fortress' of whiteness. That fortress is strengthened by what she calls the 'political-ideological apparatus' that is the 'white immune system':

"Through it, many antibodies have been secreted. Among them, humanism and the monopoly of ethics. You are the greatest antiracists. Haven't you, time and time again, celebrated the struggle of Martin Luther King against segregation? You are the most appalled by anti-Semitism. (...) You are the greatest anticolonialists. Didn't you prostrate yourselves before the courage and abnegation of Nelson Mandela? (...) You are the greatest feminists. Didn't you devote your attention to the fate of Afghan women and promise to save them from the Taliban's claws? You are the most antihomophobic. Didn't you rush head first to the defense of homosexuals in the Arab world? How could we possibly climb to your level? We are gnomes, you are giants." (Bouteldja, 2017, pp. 43-44)

Indeed, from the fortress of whiteness it has been possible to do all that, to embrace humanism, equality, ethics, anti-racism, feminism, anti-homophobia, and to nonetheless occupy a sovereign position from which to poke at 'others' and fortify particular privileges (euphemized as 'policy-relevant research'), and even to denounce all that as 'neo-colonial'! But, Bouteldja says, the immune system is weakening. It is weakening because it becomes clear that it was, in the first place, based on a 'deal' with capital. Here, Bouteldja's argument runs along similar lines to that of W.E.B. Du Bois, when he spoke of a 'public, psychological wage' that accrued to those who understood themselves as 'white' (Du Bois, 1935, pp. 700-701; cf. Du Bois, 2007, p. 14). The deal was: participate in white supremacy and get a few crumbs of capital, but by any means don't form an antagonism against capital across what $\mathrm{Du}$ Bois called 'the color line'. Bouteldja rightly sees this deal falter in our time, and so the entire project of 'integrating' people in a 'welfare state' is rapidly becoming an anachronism. And this offers opportunities, because social democracy only ever was a way of consolidating what Roediger (2007), following Du Bois, has called the 'wages of whiteness'. And Bouteldja 
offers another vocabulary altogether to speak about the potential meeting of what, up to now, have been racial interests:

"I no longer believe that this series of missed encounters between you and immigration were simply due to coincidence. I am beginning to understand that the site of a real encounter can only happen at the crossroads of our mutual interests - the fear of civil war and chaos - the site where races could annihilate each other and where it is possible to imagine our equal dignity. Because I tend to give in to sentimentality, I wonder if this isn't the space of love. Revolutionary love." (Bouteldja, 2017, pp. 49-50)

Love is a thoroughly un-academic way of speaking about sociality as entanglement, as being-together. That is its strength. What passes as 'scientific knowledge' in matters of migration, integration and super-diversity has, up to now, been possible by way of participating in the governing of the white fortress. It has been predicated on the very claim to be able to 'produce knowledge' about others from positions of privilege, to which those very same 'others' were, by and large, refused entry. And it has been legitimated by the good will to power according to which all efforts were directed at inclusion', at giving access to those lofty positions of power-knowledge to those others. But this is the situation of Europe: there was a deal with capital, and it is fading. There are movements of consolidation, and as part of this new forms of fascism are on the rise, sometimes euphemistically called 'alt-right', sometimes simply called 'populism'. And then there are those who work in universities and state-led research institutes to study as best as possible the 'complexity' of a world no longer characterized by the illusion of sameness that the deal with capital gave credibility to. 'Bazaar sociologists' is Bouteldja's word for them, for us. 'Self-proclaimed experts' (Bouteldja, 2017, p. 110). Indeed, what else is this thing we call 'autonomous science' but a self-proclamation that enables the continued production of self-same so-called 'top scientists'?

Is that cynical? I honestly don't think that that's the cynical part of this story. It is rather illegible from within the research community. Bouteldja, certainly, is speaking from a position that is nearly illegible from within the European migration apparatus: a position of indigeneity. In France, this is a productive affront because it is deemed an impossibility given the 'Republican' idea(l) that everyone is 'French', which has always been a European example of the ways 'equality' can be a mode of naturalizing racial hierarchies (cf. Hartman, 1997). In other Western-European countries, it is an affront because it is considered a position that should be abandoned, and the very abandonment of this position is what concepts such as 'integration' and 'modernity' are meant to describe, even though they keep on reproducing it in a purely asymmetrical and ascribed way. Bouteldja, on the other hand, claims indigeneity, owns it, and severs it from anything that state apparatuses such as 'migration studies' would seek to ascribe to it. For Bouteldja and her comrades, indigeneity exists in France, because France was, and is, a colonial state. And, as she recounts, she has never felt as free as when she started to use these words: indigeneity, whiteness, colonialism: "ever since then, we've provoked hatred, violence, fear, and respect. But never paternalism. Not a single person opens their mouth to talk to us about integration" (Bouteldja, 2017, pp. 118-119). That's what it took to silence the 'integration' chatter. It took the shock of shattering an immune system so 'scientifically' validated. Now, picture a meeting between Bouteldja and some representatives of the cutting edge and the 
state-of-the-art of migration studies, the latter explaining to her, with all the weighty earnestness in which academic prestige is donned, that it's really all very complex nowadays: 'you see, we now live in a super-diverse condition'. What could be more ridiculous, and more ridiculously blind to the impudent imposition 'migration studies' was and is?

The entire atmosphere of Bouteldja's intervention - and she herself reports an experience of 'suffocating' - is one of the complete and utter denunciation of anything dominant institutions purport to produce under the heading of 'knowledge' about those calibrated as 'immigrants'. Of course, the 'scientist' will shove this intervention aside it's not 'neutral', not 'objective', after all. But are there also ways of becoming attuned to the ways in which the very practice and definition of what we, as academics, claim to do, is already an imposition?

\section{All there is}

We have, over time, refined and recalibrated our vocabularies, our classifications, our techniques. We have gone from 'guest workers' to 'minorities', some of us have dabbled in 'race relations', others in 'integration', yet others have favored 'assimilation', and currently many are adopting versions of 'diversity' as in 'super-diversity'. At each step, it made for extensions of CV's, leading to papers, books, edited collections, conferences, networks, trips abroad, wining and dining. That this circle of career building through intra-academic grooming, well-funded through the extra-academic grooming that goes by the name of 'policy relevance', could continue for so long has to do with the fact that it occurred under the protective umbrella of 'Science', of the fiction of discovery and the accumulation of knowledge that none of us ever honestly felt had really reserved a place for us but that nonetheless figured as the horizon legitimating our endeavors. But frankly, I'm not buying it anymore. There's no room for recalibration here, for fine-tuning, for nuance, for getting a better empirical fit or for overhauling, once again, the parameters of the system through which we reward ourselves. I'm not buying that 'super-diversity' is an incremental step on the right track, that it is an advance, an improvement, that it abandons the problematic and indefensible position that holds that we are always beholden to positionality, always held by a collective of which we already have the name, be it 'society' or 'Europe' or 'modernity' or even 'equality'.

You see, there has to come a point at which, when we recognize that the subjects of our concerns, our studies, don't recognize themselves in the terms of those concerns and don't think of themselves as 'integrated' or as (part of anything) 'super-diverse', or as 'immigrant' or as 'refugee', as 'modern' or not, we need to confess, in good STS spirit, that we have invented whole categories of beings. And if we have invented them but if they don't find recognition by those to whom we assume the categories apply, then at some point we need to account for our inventions, to account for why we invented them in the first place, and to account for the ways we have helped invent categories that allow the free reign of fear to attach to them - and isn't this what marks our era in Western countries first and foremost? Isn't this what self-servingly legitimates our inventions as contributions to the management of people to whom categories of fear are attached? And so we may be asked why we invented these categories, and not other things. And we may be asked why we invented them ourselves, by ourselves, as a way of inventing ourselves, and not in common collaboration with those to whom we deemed our inventions applicable. 
Some of my interlocutors worry that I have not gone far enough in sketching out an alternative route. But what if the alternative is just another shape of the imposition that migration studies constitutes? What if an alternative would be the imposition of, in yet another way, clinging to the very idea of positions and positionality that ordered the empirical 'thing' that can be called 'migration' in the first place? Insofar as what is called 'migration studies' is an extended accretion of resources and privileges, I am happy not to sketch out an alternative at all. I'd rather simply go and do something else. To be 'unscientific', yes please! There are too many things I have to learn. So many generous offers for living together in dignity are on the table: conviviality, commoning, composition - these are concepts of cum rather than of in, of being-with rather than being in- or outside. Ultimately, they are modalities of the offer sketched by Bouteldja, the offer of love, revolutionary love. And that is all.

Funding

No funding was acquired for this paper.

Availability of data and materials

Data sharing not applicable to this article as no datasets were generated or analysed during the current study.

Authors' contributions

The author read and approved the final manuscript.

\section{Competing interests}

The author declares that he has no competing interests.

\section{Publisher's Note}

Springer Nature remains neutral with regard to jurisdictional claims in published maps and institutional affiliations.

Received: 8 April 2019 Accepted: 8 May 2019

Published online: 01 August 2019

\section{References}

Ahmed, S. (2012). On being included. Racism and diversity in institutional life. Durham: Duke University Press.

Baldwin, J. (1998). Collected essays. New York: The Library of America.

Bourdieu, P. (2012). Sur l'État. Cours au Collège de France 1989-1992 [On the State. Lectures at the Collège de France, 1989-1992]. Paris: Seuil.

Bouteldja, H. (2017). Whites, Jews, and us. Toward a politics of revolutionary love. Los Angeles: Semiotext(e).

Césaire, A. (2000). Discourse on colonialism. New York: Monthly Review Press.

Dijstelbloem, H., van Reekum, R., \& Schinkel, W. (2017). Surveillance at sea: The transactional politics of border control in the Aegean. Security Dialogue, 48(3), 224-240.

Du Bois, W. E. B. (1935). Black reconstruction in America: 1860-1880, (pp. 700-701). New York: The Free Press.

Du Bois, W. E. B. (2007). The world and Africa, (p. 14). Oxford: Oxford University Press.

Fanon, F. (2002). Les damnés de la terre [The wretched of the earth]. Paris: La Découverte.

Favell, A. (2019). Integration: twelve propositions after Schinkel. Comparative Migration Studies, 7. https://doi.org/10.1186/ s40878-019-0125-7.

Grünell, M., \& Saharso, S. (1999). Bell hooks and Nira Yuval-Davis on race, ethnicity, class and gender. The European Journal of Women's Studies, 6, 203-218.

Hadj Abdou, L. (2019). Immigrant integration: the governance of ethno-cultural differences. Comparative Migration Studies, 7. https://doi.org/10.1186/s40878-019-0124-8.

Hartman, S. (1997). Scenes of subjection. Terror, slavery, and self-making in nineteenth-century America. Oxford: Oxford University Press.

Klarenbeek, L.M. (2019). Relational integration: a response to Willem Schinkel. Comparative Migration Studies, 7. https://doi.org/ 10.1186/s40878-019-0126-6.

Meissner, F. (2019) Of straw figures and multi-stakeholder monitoring - a response to Willem Schinkel. Comparative Migration Studies, 7. https://doi.org/10.1186/s40878-019-0121-y.

Penninx, R. (2019). Problems of and solutions for the study of immigrant integration. Comparative Migration Studies, 7. https:// doi.org/10.1186/s40878-019-0122-x.

Roediger, D. (2007). The wages of whiteness. Race and the making of the American working class. London: Verso.

Van Reekum, R., \& Schinkel, W. (2017). Drawing lines, enacting migration: Visual prostheses of bordering Europe. Public Culture, 29(1), 27-51.

Vertovec, S. (2019). Talking around super-diversity. Ethnic and Racial Studies, 42(1), 125-139.

Wekker, G. (2016). White innocence. Paradoxes of colonialism and race. Durham: Duke University Press.

Wynter, S. (2015). Unparallelled catastrophe for our species? Or, to give humanness a different future: Conversations. In K. McKittrick (Ed.), Sylvia Wynter: On being human as praxis, (pp. 9-89). Durham: Duke University Press. 